\title{
Pronunciation intelligibility of one Cameroonian English speaker to Brazilian listeners
}

\author{
Neide Cesar Cruz \\ Universidade Federal de Campina Grande \\ neidecruz@uol.com.br \\ Raquel Carolina Ferraz D’Ely \\ Universidade Federal de Santa Catarina \\ raqueldely@gmail.com
}

\begin{abstract}
This study aims at answering the following questions: (1) which pronunciation features in the English spoken by one Cameroonian are likely to affect her speech intelligibility to Brazilian listeners? and (2) how far do these features diverge from the Brazilian way of pronouncing English? Speech samples containing pronunciation features which characterize the Cameroon English variety were presented to ten Brazilian listeners unfamiliar with this variety. They were asked to carry out two tasks: (1) to write down the samples; and (2) after having received the samples orthographic transcript, to explain the reasons for their difficulties in recognizing the words. The results reveal that words in the speech of the Cameroonian containing pronunciation features which diverge from the Brazilian way of pronouncing English were more unintelligible.
\end{abstract}

Keywords: pronunciation intelligibility. Cameroon English. Brazilian listeners.

\section{Resumo}

Este estudo visa responder duas perguntas: (1) que aspectos de pronúncia no inglês falado por uma camaronesa afetam a inteligibilidade da sua fala para ouvintes brasileiros? e (2) até onde esses aspectos divergem da forma como brasileiros pronunciam inglês? Amostras contendo características de pronúncia do inglês camaronês foram apresentadas aos brasileiros, que foram solicitados a realizar duas tarefas: (1) escrever as amostras; e (2) após terem recebido a transcrição ortográfica das amostras, explicar as razões das suas dificuldades em reconhecer palavras. Os resultados revelam que vocábulos Horizontes de Linguística Aplicada, ano 14, n. 2, 2015 
contendo aspetos de pronúncia que divergem da forma brasileira de pronunciar inglês foram mais ininteligíveis.

Palavras-chave: inteligibilidade de pronúncia. inglês camaronês. ouvintes brasileiros.

\section{Introduction}

Intelligibility has become an extensively researched construct, and has a pervasive role for the understanding of what lies behind successful communication. An important intelligibility variable is the effect of listeners' familiarity with the speakers' accent (FIELD, 2003; PICKERING, 2006; NELSON, 2011), more specifically the effect of listeners' exposure to a particular accent, or knowledge of that accent. Scholars have found that familiarity enhances intelligibility (SMITH; BISAZZA 1982; DERWING; MUNRO, 1997), and lack of it hinders intelligibility (DETERDING, 2005). In line with these investigations, this study focuses on the pronunciation intelligibility of one Cameroonian speaker of English as a Second Language (ESL) to Brazilian listeners, unfamiliar with the Cameroonian's English variety, and, although being exposed to American movies and songs, they are familiar mainly with the Brazilian way of pronouncing English, which, actually, characterizes their own pronunciation.

The study was motivated by a real life situation, in which one Cameroonian speaker of ESL, taking part in the PEC-G Program, came to a Federal University in Brazil, to be an undergraduate student majoring in English. The PEC-G is a Brazilian Government Program, which offers undergraduate courses to citizens of developing countries, with which Brazil maintains educational and cultural agreements ${ }^{1}$. The

\footnotetext{
${ }^{1}$ For further information about the Program access

http://portal.mec.gov.br/index.php?Itemid=530id=12276option=com_contentvimost

Horizontes de Linguística Aplicada, ano 14, n. 2, 2015 
Cameroonian and the Brazilian listeners taking part in the same undergraduate course have reported difficulties in understanding each other when interacting in English. This study is thus an attempt to answer the following questions: (1) which pronunciation features in the English spoken by the Cameroonian are likely to affect her speech intelligibility to Brazilian listeners? and (2) how far do these features diverge from the Brazilian way of pronouncing English?

\subsection{Intelligibility definition}

Considering that our data is derived from the Brazilian listeners` orthographic transcripts of the samples produced by a Cameroonians in this study we adopt Smith and Nelson`s (1985, p. 334) intelligibility definition: "word/ utterance recognition".

\subsection{Cameroon English Pronunciation}

In order to verify whether the Cameroonian's pronunciation actually represented the Cameroon English variety, two descriptions provided each in Atechi (2004) and Kouega (2013) served as a guideline for the identification of the pronunciation features in her speech.

Atechi (2004) presents the Cameroon English sound system divergent from RP (Received Pronunciation), regarded as being the model adopted for education in the country. Kouega (2013) presents the Cameroon pronunciation features on the basis of recordings produced by educated speakers, such as teachers, journalists, doctors. An overview of these features is presented, grouped into four categories.

\subsubsection{Stress placement}

Stress tends to be different from RP. One difference is that words are stressed one or two (occasionally three) syllables 
later than in RP, as in an'cestor, different from 'ancestor. In some cases stress is established one or two syllables earlier in the word, as in 'extreme, diverging from ex'treme.

\subsubsection{Vowels}

Apparently there is a lot of variation in vowel production in Cameroon English, probably depending on the speaker's knowledge of other languages. The central vowel [3:] is rendered as [i], [a], $[\varepsilon]$ and $[0] ;[\Lambda]$ is produced as [0], such as in bus [bos]; and [ə] as [ع], [a], [o], [u], [i], [ia], [e] and [o].

The front vowel $[æ]$ is rendered as $[a]$.

\subsubsection{Diphthongs}

The diphthong [eI] is realized as [e], [a] and $[\varepsilon]$. [əu] is rendered as [o] and [o].

\subsubsection{Consonants}

The dental fricative $[\theta]$ is pronounced as $[t]$, and [ð] as [d].

\subsection{Brazilian English Pronunciation}

The Brazilian English Pronunciation (BEP) features are also grouped into four categories. Descriptions of the sounds Brazilians are likely to have difficulties to pronounce, provided in Lieff and Nunes (1993), Baptista (2001), Lieff, Pow and Nunes (2011) and Silva (2012) served as a guideline for the identification of the BEP. Examples of Brazilian learners' spontaneous speech data revealed in Cruz $(2003 ; 2004)$ are also used. 


\subsubsection{Stress placement}

English stress patterns cause difficulties. The word comfortable tends to be pronounced with the stress on the syllable '- ta'. Brazilian learners' spontaneous speech data reveals stress on the second syllable, as in efforts [ $\varepsilon^{\prime}$ foxts], and on the first, as in terrific terrific ['texifəki].

\subsubsection{Vowels}

The central vowel [3:] tends to be nasalized when followed by $[\mathrm{m}]$ and $[\mathrm{n}] .[\Lambda]$ is likely to be pronounced as [a], and as [0], in love and cover, owing to spelling pronunciation. There is likely to be difficulty producing the central vowel [ə] in connected speech. Brazilian learners' spontaneous speech data reveals $[\varepsilon]$ pronounced instead of [ə] in weak forms of function words, as in [ðع].

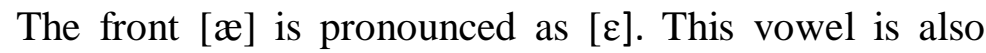
pronounced as [a], since Brazilians tend to treat the English [æ] and the Portuguese [a] as similar sounds, related to the spelling 'a'.

\subsubsection{Diphthongs}

Brazilians rarely have problems in pronouncing the English diphthongs.

Consonants

The dental fricative $[\theta]$ is pronounced as $[t]$, $[s]$ or $[\mathrm{f}]$, and $[ð]$ as $[\mathrm{d}],[\mathrm{z}]$ or $[\mathrm{v}]$.

\section{Method}

\subsection{Participants}

Ten Brazilian listeners and one Cameroonian speaker of ESL, enrolled in the same undergraduate course majoring in English, at a federal university in Brazil, took part in this study. 
The listeners' ages ranged from 21 to 24 . None of them had travelled abroad, either for study or tourism purposes. All of them informed that English was the medium of communication among them in their English classes, and reported having no difficulties in understanding their lecturers and classmates. They were, thus, familiar with the Brazilian way of pronouncing English. They also reported listening to American and British English through their course book recordings, films, music and TV series, but did not inform the specific American and British variety. Four reported having the habit of interacting in English in the internet, through the Skype software: two with 1 American, and the remaining 2 with 1 Arabic and 1 French. None of them, thus, had listening experience or familiarity with Cameroon English ${ }^{2}$.

The Cameroonian speaker was 28 years old, and had graduated in International Relations. Despite having been born and brought up in the Eastern, Francophone part of Cameroon, English was her language of instruction at school, and French was learned on the streets. She also spoke four indigenous languages and Brazilian Portuguese.

\subsection{Data collection}

We first intended to elicit the data from a natural setting. The Cameroonian was invited to talk freely and informally about topics related to her culture, in a classroom at the university. Two topics were chosen: wedding and funeral traditions in the Ewondo tribe. ${ }^{3}$ The Brazilians were instructed to interrupt her, in cases where they were unable to understand her, and she was aware of the instruction given. Our intention was to identify

\footnotetext{
${ }^{2}$ These facts were unveiled through a profile questionnaire, administered prior to the beginning of the study.

${ }^{3}$ Ewondo is a tribe of the Beti Ethnic Group.

Horizontes de Linguística Aplicada, ano 14, n. 2, 2015 
communication breakdowns, and explain the reasons for the misunderstandings.

All of the ten listeners were informed that they would be audio-recorded, and gave their consent for the recording and for use in research. A digital portable minidisc recorder Sony MZR37, with a stereo microphone, was used to ensure high quality sound.

The Cameroonian speech lasted about 30 minutes. None of the 10 listeners interrupted her. Their participation was restricted to asking her additional questions about the two topics.

After the audio-recording, in the absence of the Cameroonian, the 10 listeners were asked about her speech intelligibility. They reported us that they had been unable to understand stretches of her speech, but were reticent to interrupt her. This reticence reveals that negotiation is not a precondition for intelligibility to occur. Owing to this, a second step for data collection procedures was added.

Eleven samples containing words with the Cameroonian's English Pronunciation (CEP) features were selected from her speech (see Appendix), and presented, in a language laboratory, to the 10 listeners. Three criteria were adopted for the selection: (1) they contained lexical items the listeners should be familiar with, so that only pronunciation would be investigated; (2) they had been produced with relatively normal speed; and (3) they had to be short, so that memory constraints would not interfere with intelligibility. Considering this set of criteria, as well as the listeners' time schedules, as they had already participated in the first part of the data collection, the selection of 11 samples seemed to be reasonable considering their time availability.

The participants were informed that the samples had been produced by the invited Cameroonian speaker, during the audiorecording, which had occurred five days prior to the second data collection step. They were asked to listen to the samples 
once, and write down what they had heard. After this, they were given the samples orthographic transcript, and asked to explain the reasons for their difficulties in recognising the words. ${ }^{4}$

\section{Analysis and results}

The CEP in the 11 samples is illustrated in 22 target words selected to investigate her speech intelligibility (see Appendix). These words contain pronunciation traces which conform to the Cameroon English variety as described in Atechi (2004) and Kouega (2013). The analysis follows the 4 categories of pronunciation aspects into which the CEP and the $\mathrm{BEP}$ are grouped. In order to verify whether the pronunciation features in the English spoken by the Cameroonian were either more or less intelligible, we established that incorrect transcriptions by more than $50 \%$ of the listeners meant less intelligible, and, conversely, correct transcriptions by more than $50 \%$ meant more intelligible. The divergences and convergences identified between the CEP and the BEP are used to infer the reasons for the correct and incorrect transcriptions.

\subsection{Stress placement}

Stress placement comprises two cases: (1) daughter [do'ta], our daughter is working, stressed on the second syllable; and (2) generally [dzene'rali ], people generally get married once, stressed on the third. These two cases conform to examples of stress patterns by Brazilians, such as e'fforts and comfor'table, both stressed on the second and third syllable respectively. Generally was recognized correctly by the 10 listeners and daughter by 6 . The remaining 4 wrote instead. We

\footnotetext{
${ }^{4}$ This is adapted from Silva (2000).

Horizontes de Linguística Aplicada, ano 14, n. 2, 2015
} 
acknowledge that this is a very unusual mishearing, since it makes no sense in the sentence itself. The convergence existing between stress patterns in the speech of the Cameroonian and the BEP might have influenced the listeners' high score of correct transcriptions of these words. Figure 1 presents the different scores for the two words: generally, 100\%, and daughter $60 \%$.

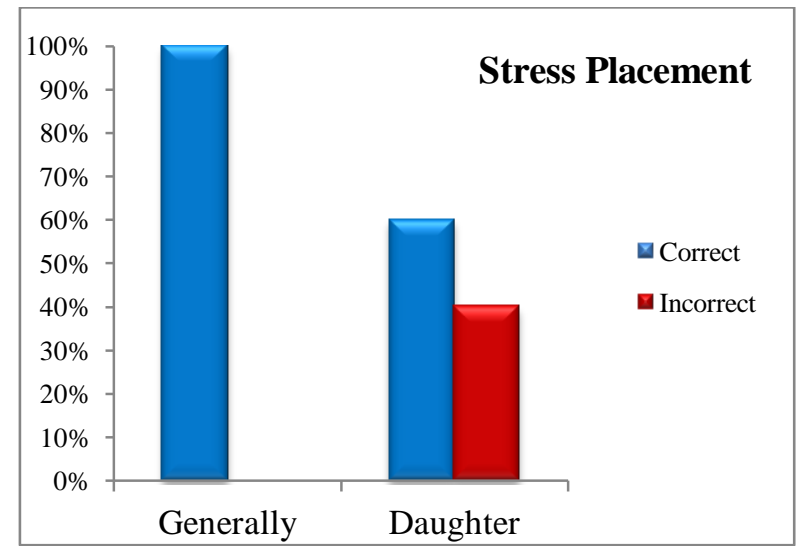

Figure 1: Stress Placement

\subsection{Vowels}

\subsubsection{Central vowels [3:], [ $\Lambda$ ] and [o]}

[3:] is produced as [0] in working ['wokin] as in our daughter is working, and works [woks] as in she works in a bank. Working and works were not recognized correctly by any listener. Working was written as walking by 9 listeners, and 1 left the space blank. In addition to vowel quality change in the stressed syllable, which reveals a divergence between the CEP and the BEP, two other reasons are likely to explain the listeners' transcription of walking. The first refers to the pronunciation of the vowel [0] in the word walk [wouk ${ }^{\mathrm{i}}$ ] by Brazilian learners (CRUZ, 2004), which is a pronunciation type the listeners might Horizontes de Linguística Aplicada, ano 14, n. 2, 2015 
be familiar with. The second is the co-text ${ }^{5}$. The word daughter produced in the same sample as working was, as previously mentioned, written correctly by 6 listeners, whose complete orthographic transcription is our daughter is walking. This transcription makes sense, and possibly explains the influence of the co-text in the listeners' transcription of walking instead of working.

Works was written walks by 8 listeners, their transcription being she walks in a bank, by 5 listeners, and walks in a bank, by 3 . The remaining 2 left the space blank. Three reasons possibly explain the listeners' transcription of walk instead of work. Two are similar to those related to walking instead of working, previously mentioned: (1) the presence of [0 ] in walk [wouk ${ }^{\mathrm{i}}$; and (2) the co-text, since both she walks in a bank and walks in a bank make sense. The third possible reason refers to the order the samples were presented to the listeners: since working was presented before works, the listeners might have made an analogy with what they had heard before, and wrote the verb walk again.

The vowel $[\Lambda]$ is rendered as [0] in coming [komin], why are you coming here? and come $[\mathrm{kom}]$, and on the day they come. This type of pronunciation converges with the BEP. Coming was written as calling by 8 listeners, the remaining 2 left the space blank. Come was transcribed as call by 6 listeners. Two reasons used to explain the listeners' transcription of walking and walks instead of working and works, previously mentioned, may be used here: (1) the co-text, since why are you calling here and and on the day they call make sense; and (2) the order the samples were presented to the listeners: coming before come. The fact that $[\Lambda]$ rendered as [0] in coming and come

\footnotetext{
${ }^{5}$ The term co-text follows Jenkins (2000, p. 81), and refers to the elements which are present in the "linguistic speech event". It is distinguished from the "extralinguistic context'.
}

Horizontes de Linguística Aplicada, ano 14, n. 2, 2015 
converges with the BEP might not have helped the listeners to recognise these two words correctly.

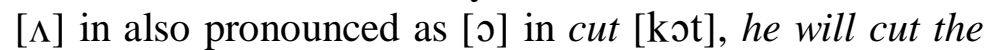
neck of the goat. This, unlike [ $\Lambda$ ] rendered as [0] in coming and come, diverges from the BEP. Cut was written as call by 8 listeners. In this case, the listeners' perception of the vowel [0] is likely to have been a phonetic clue which mostly influenced their transcriptions, since call does not make sense in the sample. In addition to this, $[\Lambda]$ pronounced as [o] diverges from the BEP, which may also have influenced the listeners' incorrect transcription.

The vowel [ə] is rendered as [e] in away [ewe], you carry your things and go away. This word was not recognized correctly by any listener. All of them left the space blank. Three aspects possibly increased the Brazilian listeners' difficulty in recognizing away correctly. First, the divergence related to the pronunciation of [ə] in the CEP and the BEP. Second, the way the diphthong in away is pronounced: it is rendered as [e]. Thus, in addition to having [ə] as [e], this word has a second sound which diverges from the BEP. The third aspect is that away follows go [gəu], whose diphthong is pronounced as [o], and was found to be a source of unintelligibility (see Diphthongs).

\subsubsection{Front vowel [ce]}

[æ] is rendered as [a] in four words: cat [kat], looking for the owner of the cat, married [ marid], people generally get married once, bank [bank], she works in a bank and carry [kari], you carry your things and go away. Since [æ] is likely to be pronounced as [a] by Brazilians in the four previously mentioned words, the Cameroonian's pronunciation here converges with the BEP. This might have influenced the listeners' transcriptions, since more than 5 wrote these words 
correctly. Figure 2 compares the intelligibility of each word in the vowel category ${ }^{6}$.

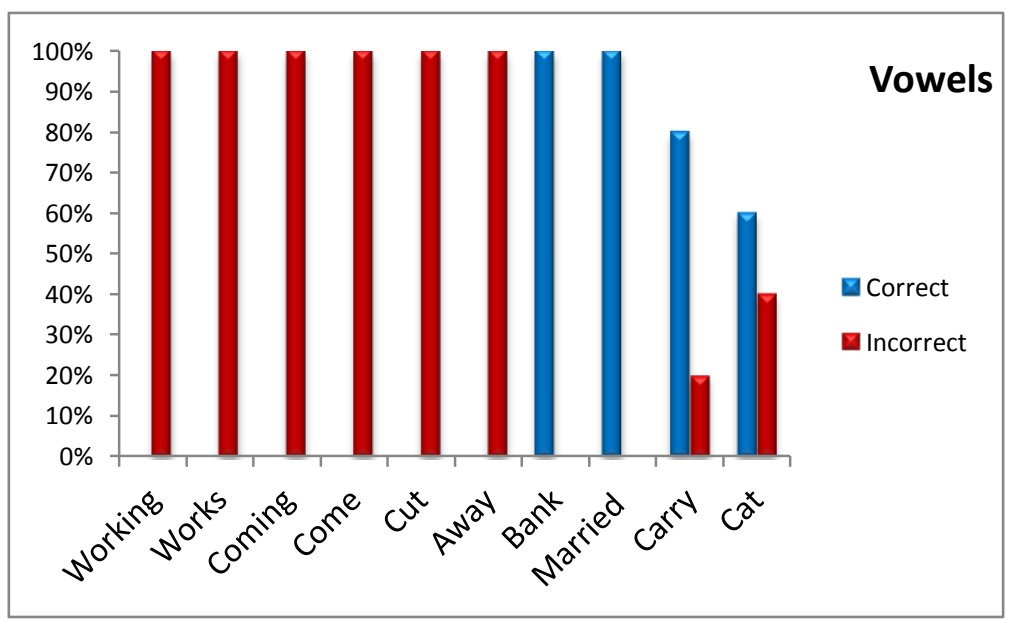

Figure 2: Vowels

Figure 2 shows a descending order of intelligibility, from the least to the most intelligible words: (1) words pronounced with the vowels [3:] and [ $\Lambda$ ] as [0], working, works, coming, come and cut, and with [ə] as [e], away, obtained $100 \%$ of incorrect transcriptions; and (2) words with [æ] rendered as [a], whose correct transcriptions varied: bank and married 100\%, carry $80 \%$ and cat $60 \%$. This reveals that the words in this category affected the Cameroonian's speech intelligibility to the Brazilian listeners in different ways.

\footnotetext{
${ }^{6}$ In the Figures, incorrect transcription stands for, not only the target words written incorrectly, but also the spaces left blank.
}

Horizontes de Linguística Aplicada, ano 14, n. 2, 2015 


\subsection{Diphthongs}

The diphthong [eI] is rendered as [e] in game [gem] and play [ple], just like a game just like a play; date [det], to announce the date; plane [plen], the plane is going; and day [de] and they [de], and on the day they come. [əu] is pronounced as [o] in owner [ona], looking for the owner of the cat; goat [got], he will cut the neck of the goat and go [go], you carry your things and go away.

One word only containing the diphthong [eI] as [e], away, was not recognized correctly by any listener. Game and they were written correctly by 5 and the remaining words by more than 5: play, date and day, by 8 listeners, and plane by 6 . Owner and go, with [əu] pronounced as [o], were neither recognized correctly by any listener, nor written as any other word. Goat was written as God, by 4 listeners and the remaining 6 left the space blank.

Both diphthongs [eI] rendered as [e] and [əu] as [o] diverge from the BEP. Despite this divergence, words with [əu] as [o] were more unintelligible than those with [e $\mathrm{I}]$ as [e].

Figure 3 compares the correct and incorrect transcriptions of the words in this category: 


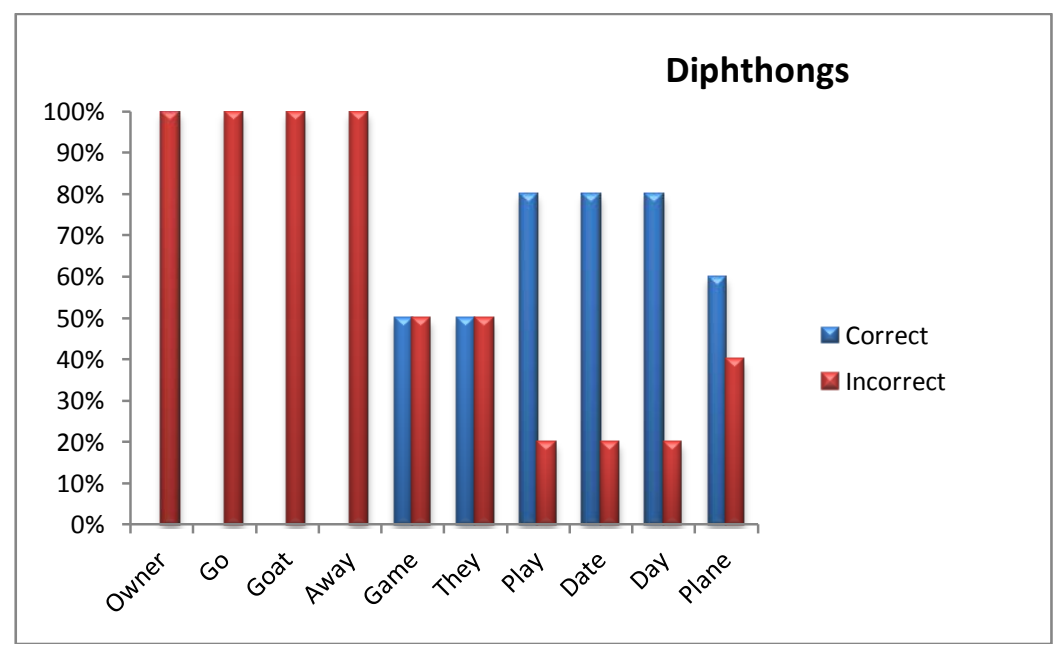

Figure 3: Diphthongs

Figure 3 shows the distinction between the transcriptions of the words pronounced with [əU] as [o] and [eI] as [e]: words with [o] obtained $100 \%$ of incorrect transcriptions, whereas those with [e], except for away, game and they, were written correctly by more than $50 \%$ of the listeners. As with vowels, previously mentioned, words containing the diphthongs differed in the way they affected the Cameroonian's speech intelligibility to the Brazilian listeners.

\subsection{Consonants}

The dental fricative $[\theta]$ is pronounced as $[\mathrm{t}]$ in things [tins], you carry your things and go away, and [ð] as [d] in they [de], and on the day they come. [ $\theta]$ pronounced as [t] and [ð] as [d] converge with the BEP of the dental fricatives. Despite this convergence, the listeners' transcription of things and they differed: things was written correctly by the 10 listeners, and they by 5 . A possible reason may be the fact that they is also Horizontes de Linguística Aplicada, ano 14, n. 2, 2015 
pronounced with the diphthong [eI] as [e], and this might have confused the listeners.

Figure 4 compares the correct and incorrect transcriptions of the words comprising this category: things, $100 \%$, and they, $50 \%$.

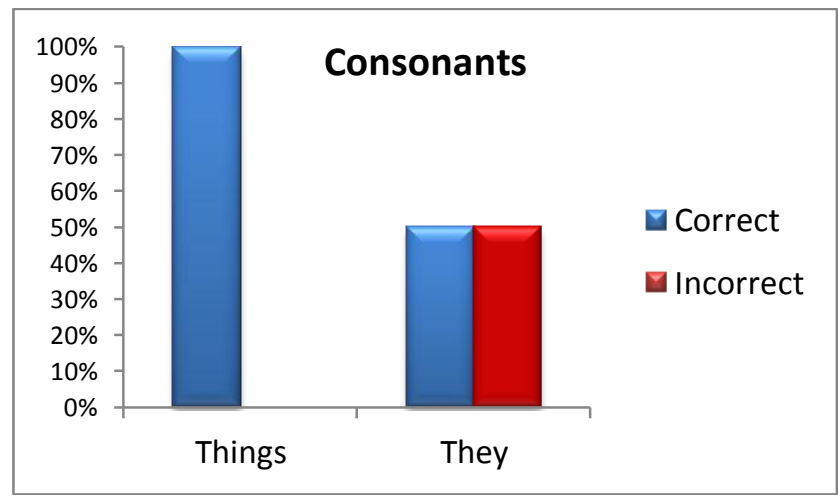

Figure 4: Consonants

The results presented in Figures 1, 2, 3 and 4 reveal that except for stress placement, the pronunciation features within the remaining categories - vowels, diphthongs and consonants affected the Cameroonian's speech intelligibility to the Brazilian listeners in different ways. Owing to this, it is necessary to consider the scores for correct and incorrect transcriptions of each pronunciation feature in these three remaining categories separately, as shown in Figure 5. 


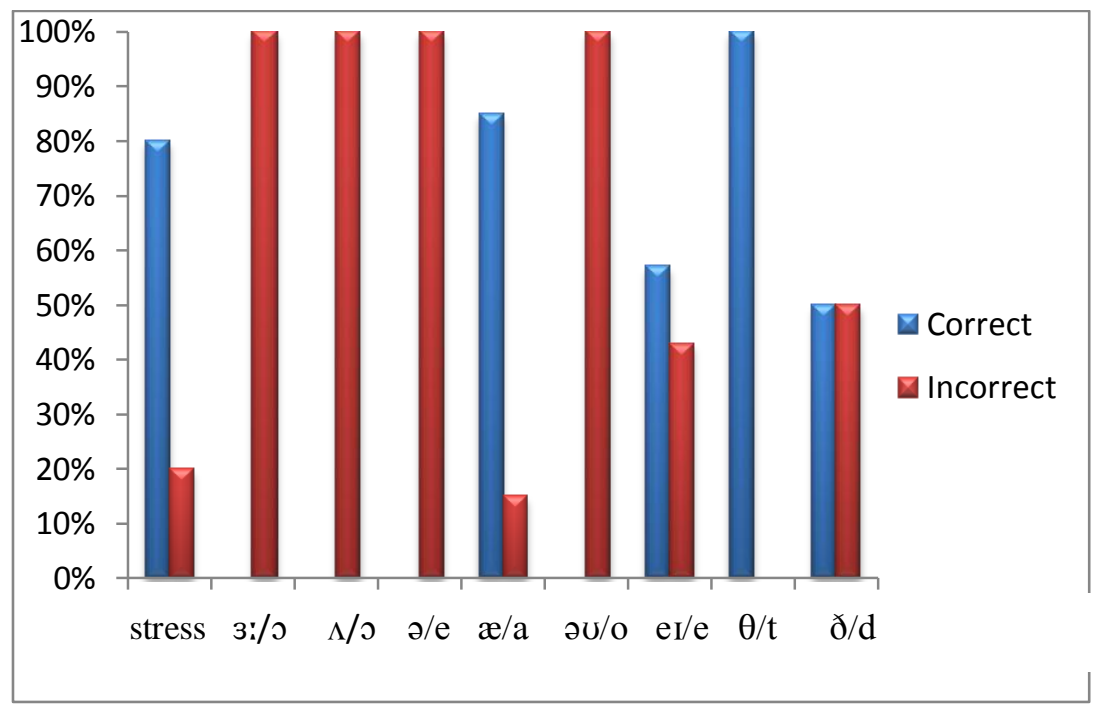

Figure 5: Pronunciation features results

On the basis of the results shown in Figure 5, we now provide answers to our two research questions.

(1) Which pronunciation features in the English spoken by the Cameroonian are likely to affect her speech intelligibility to Brazilian listeners? The results suggest a descending order, from the least to the most intelligible pronunciation feature: (1)

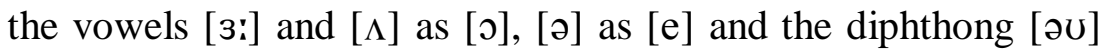
as [o], which obtained $100 \%$ of incorrect transcriptions; (2) the consonant [ð] as [d] 50\%; (3) the diphthong [eI] as [e] 43\%; (4) stress placement, 20\%; and (5) the vowel [æ] as [a] 15\%. Since we established that incorrect transcriptions by more than $50 \%$ of the listeners meant less intelligibility, and, conversely, correct transcriptions by more than $50 \%$ meant more intelligibility, the pronunciation features which obtained $100 \%$ of incorrect transcriptions affected the Cameroonian speech intelligibility more seriously. [ð] rendered as [d] was considered moderate, and the remaining features were more intelligible. We acknowledge that the highest number of target words containing Horizontes de Linguística Aplicada, ano 14, n. 2, 2015 
the target vowels and diphthongs investigated leads to more chances of incorrect transcriptions. Number of words and pronunciation features in each category was not possible to control, since the data was elicited from the Cameroonian's spontaneous speech, instead of scripted data read aloud.

(2) How far do these features diverge from the Brazilian way of pronouncing English? Out of the features which affected more seriously the Cameroonian's speech intelligibility, one only, the vowel $[\Lambda]$ as [o] in coming and come, does not diverge from the BEP. On the basis of this result, we infer that the words in the Cameroonian speech containing pronunciation features which diverge from the BEP tended to be less intelligible.

It is relevant to consider the intelligibility of the pronunciation features in the variety spoken by the Cameroonian which converges with the BEP. Out of these features, one only, the diphthong [eI] rendered as [e] does not converge. This result may suggest that the Brazilian listeners benefited from these convergences, since they were able to recognize the words containing these features correctly.

\section{Final Considerations}

In the data collection, as previously mentioned, the listeners were asked to explain the reasons for their difficulties in recognising any word. All of them found it difficult to provide any explanation, and the most common answers were I don't know and her accent. Despite their difficulties, we consider that the comment her accent is relevant, for two reasons: (1) it reinforces their lack of familiarity with the Cameroonian variety; and (2) it may explain their incorrect recognition of the words containing pronunciation features which diverge from the BEP, which is the accent they are mainly familiar with. On the basis of the result obtained here, we suggest that Brazilian learners of 
English should be exposed and be given the opportunity to become familiar with different native and non-native varieties, since they are likely to encounter speakers of these varieties, as was the case here. Moreover, familiarity is perceived as a key feature for successful task completion in the field of SLA (BYGATE, 2001; D'ELY, 2011). We acknowledge that speakers may adapt their pronunciation in order to increase their level of intelligibility. However, "many people are not able (or not willing) to modify their speech in this way" (DETERDING, 2005, p. 436).

\section{References}

ATECHI, Samuel. The intelligibility of native and non-native English speech: a comparative analysis of Cameroon English and American and British English. 2004. 264f. Doctoral Dissertation, Chemnitz University of Technology, Germany, 2004.

http://www.qucosa.de/fileadmin/data/qucosa/documents/4843/da ta/atechi_intelligibility.pdf. Access in April 9th, 2013.

BAPTISTA, Barbara. Frequent pronunciation errors of Brazilian learners of English. In: FORTKAMP, Mailce; XAVIER, Rosely. (Orgs.). EFL teaching and learning in Brazil: Theory and Practice. Florianópolis: Insular, 2001. p. 223-230.

BYGATE, Martin. Effects of task repetition on the structure and control of oral language. In: BYGATE, Martin; SKEHAN, Peter ; SWAIN, Merril(Eds.). Researching pedagogic tasks: Second Language Learning and Testing. London: Longman, 2001. p.

CRUZ, Neide. Pronunciation intelligibility in spontaneous speech of Brazilian learners' English. 2004. 241f. Doctoral 
dissertation, Federal University of Santa Catarina, Florianópolis, 2004.

An exploratory study of pronunciation intelligibility in the Brazilian learner's English. The ESPecialist, v. 24, n. 1 , p. 155-175, 2003.

D'ELY, Raquel. The Impact of familiarity with strategic planning and teacher-lead planning on learners'L2 oral performance of focused and unfocused tasks. Advanced Research in English Series, v. 9, p. 99-152, 2011.

DERWING, Tracey; MUNRO, Murray. Accent, intelligibility, and comprehensibility. Studies in Second Language Acquisition. v. 19, p. 1-16, 1997.

DETERDING, David. Listening to Estuary English in Singapore. TESOL Quarterly, v. 39, n. 3, p. 425-440, 2005. FIELD, John. The fuzzy notion of 'intelligibility': A headache for pronunciation teachers and oral testers. IATEFL Special Interest Groups Newsletter, Special issue, p. 34-38, 2003.

KOUEGA, Jean-Paul. RP and the Cameroon English accent: an overview. US-China Foreign Language, v. 11, n. 12, p. 887-900, 2013.

Available in:

http://www.davidpublishing.com/davidpublishing/Upfile/12/23/2 013/2013122365122845.pdf. Access in October 3rd, 2014.

LIEFF, Camila; NUNES, Zaina. English pronunciation and the Brazilian learner: How to cope with language transfer. Speak Out! v. 12, p. 22-27, 1993.

LIEFF, Camila; POW, Elizabeth; NUNES, Zaina. Descobrindo a pronúncia do inglês. São Paulo, Martins Fontes, 2011. 
NELSON, Cecil. Intelligibility in World Englishes: theory and application. London: Routledge, 2011.

PICKERING, Lucy. Current research on intelligibility in English as a lingua franca.

Annual Review of Applied Linguistics, v. 26, p. 219-233, 2006.

SILVA, Ricardo. A small scale investigation into the intelligibility of the pronunciation of Brazilian intermediate students. Speak out! v. 25, p. 35-42, 2000.

SILVA, Thaís Cristófaro. Pronúncia do inglês para falantes do português brasileiro. São Paulo: Contexto, 2012.

SMITH, Larry; BISAZZA, John. The comprehensibility of three varieties of English for college students in seven countries. Language Learning, v. 32, n. 2, p. 259-269, 1982.

SMITH, Larry; NELSON, Cecil. International intelligibility of English: directions and resources. World Englishes, v. 4, n. 3, p. 333-342, 1985.

\section{Appendix}

Just like a game just like a play

$$
\text { [gem] [ple] }
$$

To announce the date

$$
\text { [det] }
$$

Our daughter is working

$$
\text { [d'ta] ['wokin] }
$$

Why are you coming here?

['komin]

Horizontes de Linguística Aplicada, ano 14, n. 2, 2015 
Neide C. Cruz; Raquel C. F. D’Ely

Looking for the owner of the cat

$$
\text { [ona] [kat] }
$$

The plane is going

$$
\text { [plen] }
$$

He will cut the neck of the goat

$$
\text { [kot] [got] }
$$

People generally get married once

$$
\text { [dzene'rali ] [ 'marid] }
$$

She works in a bank

[woks] [bayk]

And on the day they come

[de] [de][kom]

You carry your things and go away

[kari] [tins] [go] [e'we]

Recebido em: 26/06/2014 Aceito em: 09/11/2015

Título: Inteligibilidade da pronúncia de uma camaronesa falante de inglês para ouvintes brasileiros 